\title{
Histone acetylation deficits in lymphoblastoid cell lines from patients with Rubinstein-Taybi syndrome
}

\author{
J P Lopez-Atalaya, ${ }_{1}$ C Gervasini, ${ }^{2}$ F Mottadelli, ${ }^{2}$ S Spena, ${ }^{2}$ M Piccione, ${ }^{3}$ G Scarano, ${ }^{4}$ \\ A Selicorni, ${ }^{5}$ A Barco, ${ }^{1}$ L Larizza $^{2}$
}

${ }^{1}$ Instituto de Neurociencias (Universidad Miguel Hernandez-Consejo Superior de Investigaciones Científicas), San Juan de Alicante, Alicante,

Spain

${ }^{2}$ Medical Genetics, Department of Medicine, Surgery and Dentistry, University of Milan, Milan, Italy

${ }^{3}$ Dipartimento Materno Infantile, Università di Palermo, Palermo, Italy

${ }^{4}$ UO Genetica Medica, AO 'Gaetano Rummo', Benevento, Italy

${ }^{5}$ Ambulatorio Genetica Clinica Pediatrica, Clinica Pediatrica Università Milano Bicocca, Fondazione MBBM AOS Gerardo Monza, Italy

\section{Correspondence to} Dr A Barco, Instituto de Neurociencias de Alicante (Universidad Miguel Hernández-Consejo Superior de Investigaciones Científicas), Campus de Sant Joan, Apt. 18, Sant Joan d'Alacant 03550, Alicante, Spain;

abarco@umh.es

Dr Lidia Larizza, Medical Genetics, Department of Medicine, Surgery and Dentistry, University of Milan, Milan, Italy;

lidia.larizza@unimi.it

$A B$ and $L L$ equally contributed to the work. JP L-A and CG equally contributed to the work.

Received 20 July 2011 Revised 1 September 2011 Accepted 2 September 2011

\begin{abstract}
Background Rubinstein-Taybi syndrome (RSTS) is a congenital neurodevelopmental disorder defined by postnatal growth deficiency, characteristic skeletal abnormalities and mental retardation and caused by mutations in the genes encoding for the transcriptional co-activators with intrinsic lysine acetyltransferase (KAT) activity CBP and p300. Previous studies have shown that neuronal histone acetylation is reduced in mouse models of RSTS.
\end{abstract}

Methods The authors identified different mutations at the CREBBP locus and generated lymphoblastoid cell lines derived from nine patients with RSTS carrying distinct CREBBP mutations that illustrate different grades of the clinical severity in the spectrum of the syndrome. They next assessed whether histone acetylation levels were altered in these cell lines.

Results The comparison of CREBBP-mutated RSTS cell lines with cell lines derived from patients with an unrelated mental retardation syndrome or healthy controls revealed significant deficits in histone acetylation, affecting primarily histone $\mathrm{H} 2 \mathrm{~B}$ and histone $\mathrm{H} 2 \mathrm{~A}$. The most severe defects were observed in the lines carrying the whole deletion of the CREBBP gene and the truncating mutation, both leading to a haploinsufficiency state. Interestingly, this deficit was rescued by treatment with an inhibitor of histone deacetylases (HDACi).

Conclusions The authors' results extend to humans the seminal observations in RSTS mouse models and point to histone acetylation defects, mainly involving $\mathrm{H} 2 \mathrm{~B}$ and $\mathrm{H} 2 \mathrm{~A}$, as relevant molecular markers of the disease.

\section{INTRODUCTION}

Rubinstein-Taybi syndrome (RSTS; Online Mendelian Inheritance in Man \#180849, \#613684) is a poorly understood autosomal-dominant disorder that affects one out of 125000 newborns. ${ }^{1}$ The disease is characterised by postnatal growth retardation, cognitive impairment, skeletal abnormalities and a high incidence of neoplasia. ${ }^{2}{ }^{3}$ Individuals with RSTS experience difficulty in planning and executing motor acts and have a short attention span and a low intelligence level with an average IO of 50 , although mental range can go from 25 to 80. ${ }^{4}$ The distinctive anatomical features, including facial dysmorphisms, hypertelorism, prominent nose, malpositioned ears and especially broad thumbs and toes, are commonly used for diagnosis that can be confirmed by genetic screen. Two genes are currently known to be responsible for RSTS: $C R E B B P$ encoding for the CAMP response element- binding protein (CREB)-binding protein (also known as CBP) and located at $16 \mathrm{p} 13.3^{6}$ and EP300 encoding for the E1A associated protein p300, highly homologous to CBP, and located at 22q13. ${ }^{7}$ Frameshift, nonsense, splice site and missense point mutations in the CREBBP locus (in decreasing order of prevalence) are found in about $50 \%$ of RSTS cases, ${ }^{6-18}$ whereas deletions of part or all of the $C R E B B P$ gene and flanking regions may account for an additional $5 \%-10 \%$ of the cases. ${ }^{13} 1920 \mathrm{~A}$ few gene-disrupting translocations and inversions have been also reported. ${ }^{6} 19$ 21-25 EP300 mutations are comparatively rare. Only seven cases have been described so far in patients with a mild clinical presentation. ${ }^{7}$ 26-29

CBP and p300 are transcriptional co-activators with intrinsic lysine acetyltransferase activity ${ }^{30}$ (KAT, previously referred to as histone acetyltransferase, ${ }^{31}$ HAT) that act in different signal transduction pathways and are involved in the control of cell growth, cellular differentiation, DNA repair, apoptosis and tumour suppression. ${ }^{32} 33$ They also play an important role in the development of the skeletal and central nervous systems. Although little is still known about the specific epigenetic modifications associated to this syndrome, as well as its relative significance in terms of transcriptional defects, the deficiency on KAT activity during development and in adulthood seems to be the most likely cause of RSTS symptoms.

Studies in mouse models of RSTS have provided valuable information on RSTS aetiology and revealed a critical role for CBP's KAT activity in cognitive processes. ${ }^{34-38}$ These studies have shown that the loss or reduction of CBP is associated with reduced bulk levels of histone acetylation in the brain. In $c b p^{+/-}$mice, the model that better reproduces the genetic alteration found in most patients with RSTS, the acetylation of histone $\mathrm{H} 2 \mathrm{~B}$ is particularly affected, ${ }^{36}$ whereas in neurons of CBP conditional knockouts, all four histones are affected, but the deficit in acetylation is still stronger in the case of histones H2B and H2A. ${ }^{39-41}$ No significant reduction of bulk histone acetylation was observed in the hippocampus of p300 hemizygous mice, which show very mild cognitive deficiencies, strengthening the correlation between reduced neuronal histone acetylation and cognitive impairments. ${ }^{42}$

The main objective of this study is to investigate whether histone acetylation is also affected in patients with RSTS. Towards this end, we have selected a group of patients with RSTS who carry different molecular lesions of CREBBP and are 
therefore representative of the main types of causative mutations. We obtained lymphoblastoid cell lines from these patients and examined the consequences of the mutation in bulk histone acetylation. The results of these experiments extend our seminal findings in crebbp mutant mice and revealed that histone acetylation deficits are concomitant with cognitive impairments also in humans.

\section{MATERIALS AND METHODS Patients}

One hundred ten individuals clinically diagnosed as having RSTS were genetically tested for mutations of the CREBBP gene. This scan identified a cohort of CREBBP-positive patients with RSTS, consisting of 43 patients carrying heterozygous point mutations and 7 carrying deletions in one allele. Among these cases, we selected nine patients representative of the wide clinical variability of the syndrome and its allelic heterogeneity. They all show skeletal abnormalities with broad thumb or hallux and have typical facial features of RSTS with psychomotor and mental retardation ranging from mild to severe. Malformations and other signs of the disease were reported in some patients. See table 1 for additional details. The patients with Cornelia de Lange syndrome (CdLS) all carry heterozygous mutations in the NIPBL gene.

\section{Molecular test of CREBBP mutation and bioinformatic analysis}

As a first step in our study, we performed fluorescence in situ hybridisation (FISH) analysis to detect total or partial deletions in the CREBBP gene in those samples in which chromosome spreads could be set up. Then, we screened the coding region of the $C R E B B P$ gene by denaturing high-performance liquid chromatography (DHPLC) and direct sequencing. Bacterial artificial chromosome-FISH (BAC-FISH) on the genomic region harbouring $C R E B B P$ gene and DHPLC/DNA sequencing of all coding exons of $C R E B B P$ were performed as previously described. $^{12} 20$ Reverse transcriptase-PCR (RT-PCR) analysis of mutated alleles was also performed as previously described. ${ }^{12}$ All the detected mutations were searched and confirmed in the corresponding cell lines. BAC clones for FISH analysis were selected according to Genome Browser (http://genome.ucsc.edu). PCR conditions for DHPLC screening were determined using the software Optimase Protocol Writer. ClustalW2 (http://www.ebi. ac.uk/Tools/clustalw2/index.html) was used to analyse the amino acidic sequence alignment of human CBP versus Drosophila, Caenorhabditis elegans and murine CBP, and versus human p300. PolyPhen (http://coot.embl.de/PolyPhen) was used for prediction of the possible effect of any amino acid substitution, and the Splice Site Prediction by Neural Network (http:// www.fruitfly.org/seq_tools/splice.htm) tool at the Berkeley Drosophila Genome Project was used to predict the consequences of mutations affecting putative splicing donor or acceptor sites.

\section{Cell lines establishment, maintenance and treatment}

Lymphoblastoid cell lines from all patients and healthy individuals were established by Epstein-Barr virus transformation of peripheral blood mononuclear cells, in collaboration with Galliera Genetic Bank (Istituto Galliera, Genoa, Italy). All cells were grown in RPMI 1640 media (Sigma, Saint Louis, MI, USA) supplemented with $2 \mathrm{mM} \mathrm{L-glutamine,} 10 \%$ fetal bovine serum (Invitrogen, Camarillo, CA, USA) and penicillin/streptomycin. In trichostatin A (TSA) experiments, cells were incubated for $2 \mathrm{~h}$ with vehicle (dimethyl sulfoxide (DMSO)) or $2 \mu \mathrm{M}$ TSA in fresh media. This treatment did not affect cell viability in the time frame of our experiments.

\section{Quantitative RT-PCR}

Total cellular RNA isolation was performed using RNeasy kit (Qiagen Inc., Chatsworth, CA, USA). Reverse transcription was performed using RevertAid First Strand CDNA synthesis kit (Fermentas, St. Leon-Rot, Germany). Quantitative RT-PCR (qRT-PCR) was carried out on a ABI 7300 Real-Time PCR System (Applied Biosystems, Carlsbad, CA, USA) and amplified using SYBR GreenER qPCR reagent (Invitrogen). Each sample was assayed in duplicate and normalised using GAPDH levels. Primer sequences for amplification of CBP, p300 and GAPDH transcripts were designed using Primer Express Software V.2.0 (Applied Biosystems).

\section{Quantitative western blotting}

Western blot analyses were carried out as previously described. ${ }^{43}$ The following home-made and commercial primary antibodies and dilutions were used: rabbit anti-histone H2B (1:10000) and mouse anti-histone H3 (1:10000) (Abcam, Cambridge, UK), mouse anti $\beta$-actin (Sigma) (1:50 000); anti-acetylated histone $\mathrm{H} 2 \mathrm{~A}$ (AcH2A) (1:1000), anti-acetylated histone H2B (AcH2B) (1:10000), anti-acetylated histone $\mathrm{H3}(1: 10000)$ and anti-acetylated histone $\mathrm{H} 4$ (AcH4) $(1: 1000) .{ }^{43}$ Secondary antibodies were anti-mouse HRP (1:10000) and anti-rabbit HRP (1:10000) (Sigma).

\section{Fluorescent activated cell sorting (FACS) analysis}

Cells $\left(1-5 \times 10^{6}\right.$ cells) were fixed overnight in $70 \%$ ethanol solution at $-20^{\circ} \mathrm{C}$, pelleted and washed twice with staining buffer (phosphate-buffered saline with 1\% fetal bovine serum). A total of $1 \times 10^{5}$ cells per condition were incubated with rabbit anti-acetyl histone $\mathrm{H} 2 \mathrm{~B}$ for $30 \mathrm{~min}$ at room temperature. Cells were washed and then stained with an Alexa Fluor 488-conjugated goat anti-rabbit antibody (Invitrogen) for $20 \mathrm{~min}$ at room temperature in the dark. Washes and staining steps were performed using staining buffer. Background staining was determined in negative cell lines and with matched fluorochrome-conjugated isotype controls. Cells were analysed on a FACSAria III flow cytometer (BD biosciences, Franklin Lakes, NJ, USA).

\section{Statistical methods}

Precise description of the statistical methods used in each experiment is presented in the text. In the graphs, error bars represent SEM.

\section{RESULTS}

Characterisation of novel CREBBP mutations and transcript analysis in peripheral blood and lymphoblastoid cell lines from patients with RSTS

To investigate the acetylation state of the chromatin of cells from patients with RSTS, we obtained lymphoblastoid cells lines from peripheral blood of patients of special interest based on their clinical features and/or the nature of their molecular pathogenetic lesions. These patients were selected from a large cohort of 110 patients diagnosed as having RSTS recruited from different Italian clinical units and screened for mutations in $C R E B B P$. Among the 50 patients whose clinical diagnosis could be confirmed by molecular and/or FISH analysis of the CREBBP gene, nine were selected for further study through the generation of lymphoblastoid cell lines. This panel of patients with RSTS is representative of the different clinical manifestations of the syndrome, as detailed in table 1, and of the allelic heterogeneity at the CREBBP locus. The genetic lesions carried by the selected patients include a whole gene deletion and eight point 
Table 1 Clinical signs of the nine cell line donor patients as compared to those characteristic of patients with RSTS

\begin{tabular}{|c|c|c|c|c|c|c|c|c|c|}
\hline Patient & 41 & 75 & 99 & 114 & 20 & 46 & 98 & 84 & 127 \\
\hline Mutation/type & $\begin{array}{l}\text { Whole gene } \\
\text { deletion } \\
\text { microdeletion }\end{array}$ & $\begin{array}{l}\text { c. } 2556 \text { delC } \\
\text { p.GIn786ArgfsX21 } \\
\text { truncating }\end{array}$ & $\begin{array}{l}\text { c.85+1G } \rightarrow \mathrm{T} \\
\text { splicing }\end{array}$ & $\begin{array}{l}\text { c. } 4485- \\
7 C \rightarrow G \\
\text { splicing }\end{array}$ & $\begin{array}{l}\text { c. } 4728+ \\
1 \mathrm{G} \rightarrow \mathrm{A} \\
\text { splicing }\end{array}$ & $\begin{array}{l}\text { c. } 4627 \mathrm{G} \rightarrow \mathrm{T} \\
\text { p. Asp1543Tyr } \\
\text { missense }\end{array}$ & $\begin{array}{l}\text { c. } 2014 G \rightarrow C \\
\text { p.Leu1338Phe } \\
\text { missense }\end{array}$ & $\begin{array}{l}\text { c. } 5060 \mathrm{C} \rightarrow \mathrm{T} \\
\text { p.Ser1687Phe } \\
\text { missense }\end{array}$ & $\begin{array}{l}\text { c. } 4444 \mathrm{~T} \rightarrow \mathrm{G} \\
\text { p.Tyr1482Asp } \\
\text { missense }\end{array}$ \\
\hline Age at diagnosis & $20 y$ & Birth & Birth & $20 \mathrm{~m}$ & Birth & $20 \mathrm{~m}$ & $5 y$ & $5 y$ & $2 y$ \\
\hline \multicolumn{10}{|l|}{ Growth } \\
\hline IUGR & - & + & - & - & - & - & - & - & - \\
\hline Postnatal height & $<3^{\circ}$ & $10^{\circ}$ & NA & $<10^{\circ}$ & $<3^{\circ}$ & $<3^{\circ}$ & $<3^{\circ}$ & $25^{\circ}$ & $<3^{\circ}$ \\
\hline Feeding problems & + & NA & NA & - & NA & NA & - & + & + \\
\hline \multicolumn{10}{|c|}{ Psychomotor development } \\
\hline Sitting position & $12 \mathrm{~m}$ & NA & NA & $10 \mathrm{~m}$ & $12 \mathrm{~m}$ & NA & $13 \mathrm{~m}$ & $7 \mathrm{~m}$ & $16 \mathrm{~m}$ \\
\hline First walk & $24 \mathrm{~m}$ & NA & NA & $17 \mathrm{~m}$ & $30 \mathrm{~m}$ & NA & $18 \mathrm{~m}$ & $16 \mathrm{~m}$ & $16 \mathrm{~m}$ \\
\hline First words & $3 y$ & NA & NA & $20 \mathrm{~m}$ & $20 \mathrm{~m}$ & NA & $24 \mathrm{~m}$ & $4 y$ & $4 y$ \\
\hline \multicolumn{10}{|c|}{ Typical dysmorphisms } \\
\hline Microcephaly & + & - & + & + & + & + & - & + & + \\
\hline Prominent forehead & - & + & - & + & + & - & + & - & + \\
\hline $\begin{array}{l}\text { Downslanting } \\
\text { palpebral fissures }\end{array}$ & + & + & - & + & + & + & + & - & - \\
\hline $\begin{array}{l}\text { Prominent backed } \\
\text { nose }\end{array}$ & - & + & + & + & + & + & + & + & + \\
\hline $\begin{array}{l}\text { Columella below } \\
\text { the alae nasi }\end{array}$ & + & + & + & + & + & + & + & + & + \\
\hline Grimacing smile & - & + & - & + & - & - & - & - & + \\
\hline $\begin{array}{l}\text { High and vaulted } \\
\text { palate }\end{array}$ & - & - & + & + & + & - & + & - & - \\
\hline Other & & Polydactyly & & & & & & & $\begin{array}{l}\text { Ulnar } \\
\text { deviation }\end{array}$ \\
\hline \multicolumn{10}{|l|}{ Feet } \\
\hline Broad hallux & + & + & + & + & + & + & + & + & + \\
\hline Bifid hallux & - & - & - & - & + & - & - & - & - \\
\hline Other & & & & & & - & & & \\
\hline \multicolumn{10}{|l|}{ Major malformations } \\
\hline Heart anomalies & - & - & NA & ASD & - & - & - & - & $\begin{array}{l}\text { Fallot } \\
\text { tetralogy }\end{array}$ \\
\hline Ocular anomalies & - & - & - & - & - & NA & - & - & - \\
\hline Genital anomalies & - & - & Cryptorchidism & - & - & - & - & - & - \\
\hline Kidney anomalies & - & - & - & - & - & $\begin{array}{l}\text { Vesicoureteral } \\
\text { reflux, renal } \\
\text { hypoplasia }\end{array}$ & - & Hydronephrosis & $\begin{array}{l}\text { Vesicoureteral } \\
\text { reflux }\end{array}$ \\
\hline \multicolumn{10}{|l|}{ Medical complications } \\
\hline Ocular problems & $\begin{array}{l}\text { Myopia, } \\
\text { strabismus }\end{array}$ & - & NA & - & - & NA & - & Strabismus & - \\
\hline Dental problems & - & - & NA & - & - & NA & - & - & Malocclusion \\
\hline Hypoacusia & - & - & NA & - & - & - & - & - & - \\
\hline $\begin{array}{l}\text { Orthopaedic } \\
\text { problems }\end{array}$ & Scoliosis & - & NA & $\begin{array}{l}\text { Genu valgus, } \\
\text { pes planus }\end{array}$ & $\begin{array}{l}\text { Patellar } \\
\text { luxation }\end{array}$ & NA & - & - & - \\
\hline Keloids & - & - & NA & - & - & - & - & - & - \\
\hline Neoplasia & $\begin{array}{l}\text { Forehead } \\
\text { haemangioma }\end{array}$ & - & NA & - & - & $\begin{array}{l}\text { Multiple } \\
\text { pilomatrixoma } \\
\text { lesions }\end{array}$ & - & - & - \\
\hline
\end{tabular}


Downloaded from jmg.bmj.com on November 24, 2011 - Published by group.bmj.com

Table 1 Continued

\begin{tabular}{|c|c|c|c|c|c|c|c|c|c|}
\hline Patient & 41 & 75 & 99 & 114 & 20 & 46 & 98 & 84 & 127 \\
\hline $\begin{array}{l}\text { Individual } \\
\text { clinical } \\
\text { signs }\end{array}$ & & $\begin{array}{l}\text { Corpus callosum } \\
\text { agenesis, } \\
\text { Dandy-Walker } \\
\text { malformation }\end{array}$ & & & & $\begin{array}{l}\text { Duodenal } \\
\text { malrotation }\end{array}$ & & & \\
\hline First report & 12 & This study & This study & This study & 12 & 12 & This study & This study & This study \\
\hline
\end{tabular}

ASD, atrial septal defect; IUGR, intrauterine growth retardation; MR, mental retardation; NA, not assessed; PDA, patent ductus arteriosus; RSTS, Rubinstein-Taybi syndrome.

mutations: four missense, three splicing and a truncating mutation. Three out of these nine mutations have been previously described, ${ }^{12} 20$ while the characterisation of the remaining six patients is presented here for the first time.

\section{Missense mutations}

All missense mutations were de novo as they were searched and excluded in the probands' parents and in 50 healthy individuals. Patient 46 (c.4627G $\rightarrow$ T, p.D1543T in exon 28) has been previously described, ${ }^{12}$ while patients 84,98 and 127 are carriers of novel missense mutations (c.5060C $\rightarrow \mathrm{T}$, p.S1687F in exon 30; c.2014G $\rightarrow$ C, p.L1338F in exon 24 and c.4444T $\rightarrow$ G, p.T1482D in exon 27 , respectively). We checked whether the mutation found on the DNA could be detected at the RNA level and confirmed the presence of the aberrant transcript beside the normal one in all four cases. The comparative amino acid sequence analysis revealed that all the mutations affect amino acids that are highly conserved through evolution and in the
Figure 1 Localisation of nine CREBBP mutations (six of them of novel description) in patients with Rubinstein-Taybi syndrome. A. Schematic representation of the CBP protein with its known domains: KIX (CREB binding domain), BD (bromodomain) and KAT (acetyltransferase domain). The KAT domain (aa 1232-1709) is depicted in greater detail in the lower box indicating its putative subdomains, namely, the PHD (plant homeodomain-type zinc finger) domain with enzymatic activity (aa 1237-1311) and the coenzyme A binding site (aa 1459-1541) B. Localisation of the four missense mutations (black symbols) within CREBBP exons coding KAT domain; the three splicing mutations in IVS1, IVS25 and IVS28 (grey symbols); the truncating mutation in exon $13(+)$ and the whole gene deletion $(\mathrm{x})$. C. Splicing mutation of patient 99: reverse transcriptase-PCR (RT-PCR) (top) of the CREBBP fragment using primers in exon 1 (forward) and exon 2 (reverse) evidencing two additional longer fragments (asterisks). Diagram (bottom) showing the localisation of two cryptic donor sites leading to formation of two aberrant transcripts retaining 411 and 519 bases of intron 1, respectively. D. Splicing mutation of patient 114: RTPCR (top) of patient 114 using forward and reverse primers in exons 22 and 29 showing two additional smaller fragments (asterisks). Mechanism of missplicing (bottom) leading to two aberrant in-frame transcripts that, as shown by the electropherograms, skip exon 26 or exons 25 and 26. mw: weight markers; nc: normal control.
A

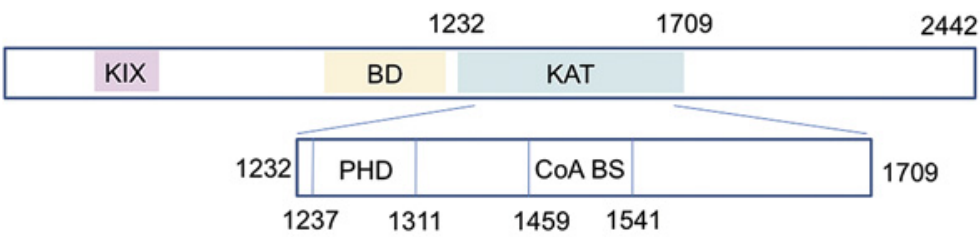

B
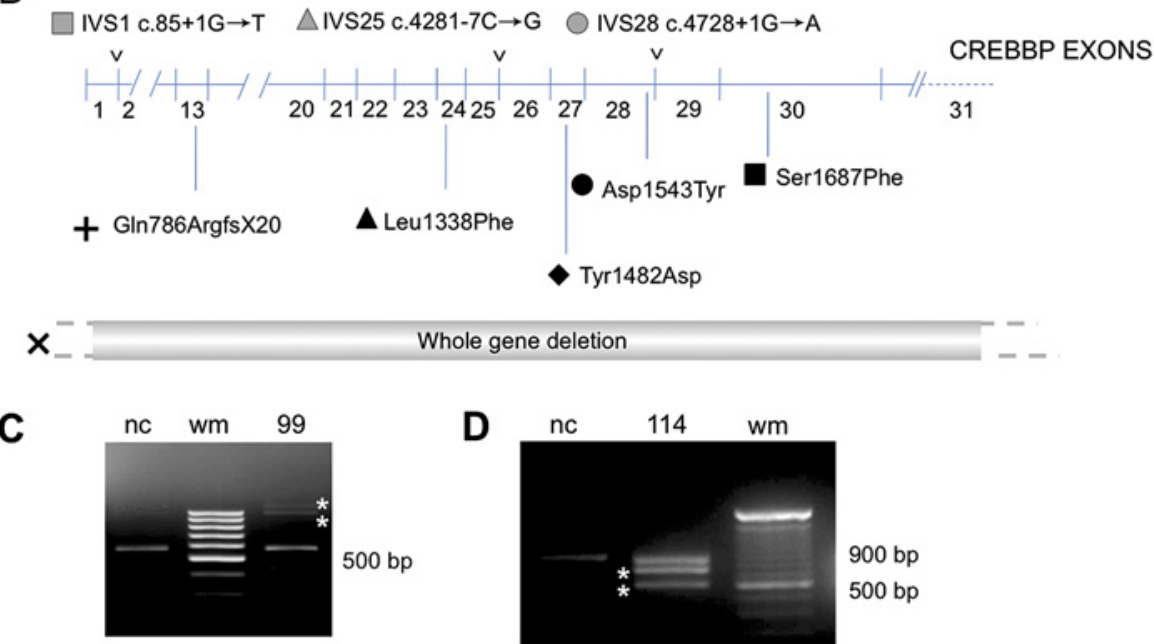

Whole gene deletion $\quad--$
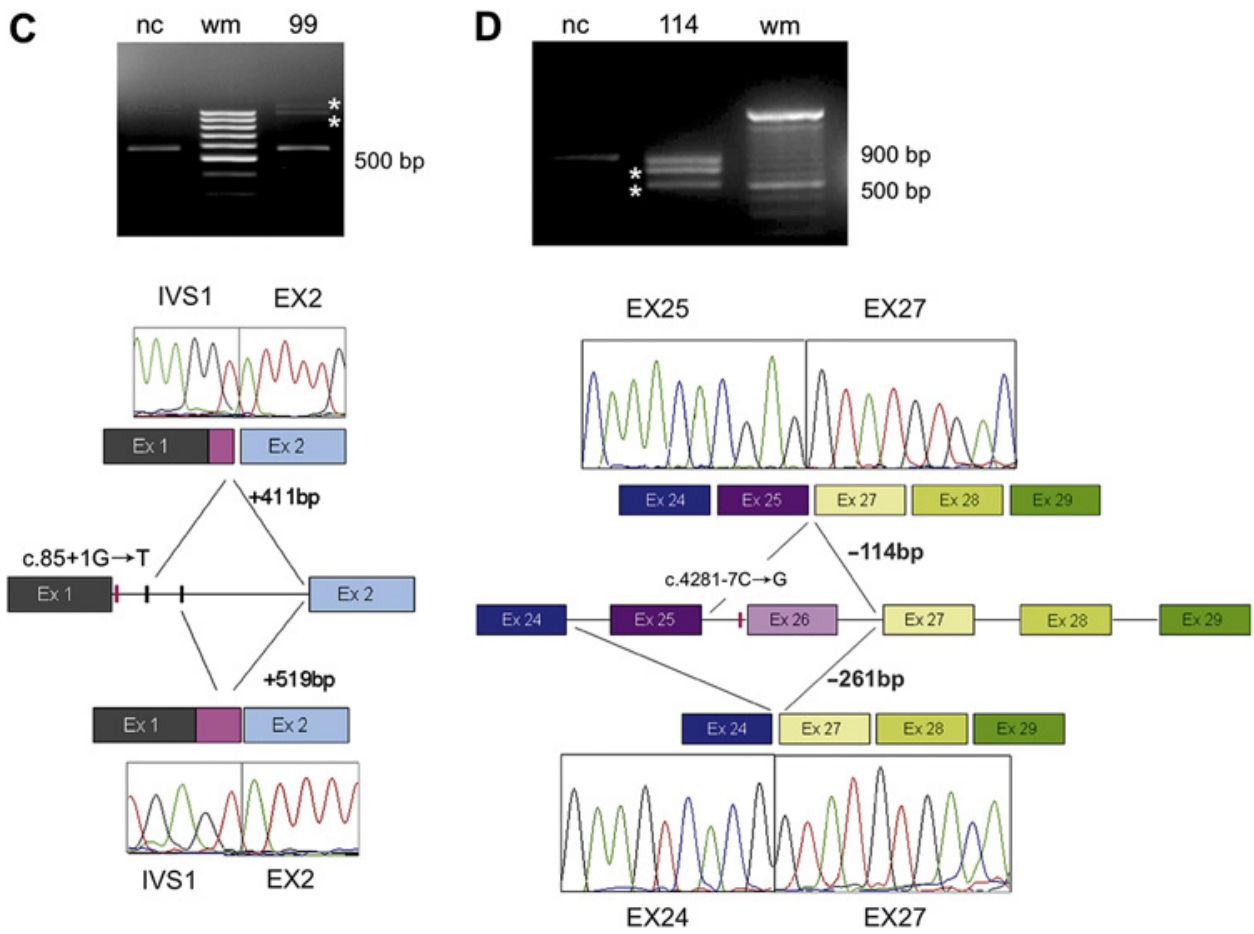
related p300 protein. All four missense mutations are located in the KAT domain (figure 1A,B). In particular, the mutation of patient 127 maps into the subdomain postulated to be the coenzyme A binding site (amino acids 1459-1541). The mutation carried by patient 46 has been confirmed also in the DNA isolated from the cheek and thigh where the patient developed the benign epithelial tumours pilomatrixomas.

\section{Splicing mutations}

Patient 20, previously described, ${ }^{12}$ and the newly identified patients 99 and 114 carry different types of splice site mutations. The mutations found in patients 20 and 99 affect canonical splicing sites and lead to the activation of cryptic exonic splice sites, whereas the mutation of patients 114 affects a "noncanonical' splicing site. In all cases, we investigated the aberrant $C R E B B P$ transcripts resulting from the missplicing. Patient 20 mutation, c. $4728+1 \mathrm{G} \rightarrow \mathrm{A}$, affecting the intervening sequence (IVS) 28 donor splice site has been found to generate a transcript skipping $104 \mathrm{bp}$ of exon 28 through the activation of a cryptic exonic donor site: the frameshift produced by missplicing should lead to the incorporation of 38 anomalous amino acids. ${ }^{12}$ The splice site mutation identified in patient 99 is a $\mathrm{G} \rightarrow \mathrm{T}$ substitution in the first base of IVS1 $(85+1 \mathrm{G} \rightarrow \mathrm{T})$ arising de novo and yet unreported. Bioinformatic analysis of the patient cDNA predicted the presence of three different transcripts: the wildtype one that appears to be expressed at the highest levels and two longer transcripts. We sequenced the two aberrant transcripts characterised by the retention of different portions of IVS1 and found that the two transcripts originate from the activation of two of the predicted donor sites with a highest score after the canonical one (figure 1C). Translation of the two aberrant transcripts is hypothesised to generate the same truncated protein of 46 amino acids. Patient 114 carries the de novo mutation c.4485-7C $\rightarrow \mathrm{G}$ affecting the nucleotide at position 7 of the consensus sequence in IVS25. According to Splice Site Prediction, this substitution leads to a decrease of the score of IVS25 acceptor site. cDNA analysis identified two aberrant transcripts, one skipping exon 26 and one skipping exons 25 and 26 (figure 1D), that keep the same frame and encode proteins lacking 49 and 87 aas, respectively.

\section{Truncating mutation}

Patient 75 carries a novel truncating mutation, c.2356delC in exon 13 leading to frameshift and predicting the truncated protein p.Q786RfsX20. RNA analysis evidenced the presence of both transcripts: the normal and the aberrant originated by the mutant allele.

\section{Whole gene deletion}

The deletion of patient $41^{12} 20$ encompasses a $500 \mathrm{~kb}$ region beyond the $5^{\prime}$ and $3^{\prime}$ ends of the CREBBP gene.

$B$ cells from these nine patients with RSTS were immortalised using Epstein-Barr virus. For comparison purposes, we also obtained lymphoblastoid cell lines from blood samples of three normal individuals and three children with CdLS, a mental retardation disorder molecularly unrelated to RSTS.

\section{Expression of CREBBP and EP300 in cell lines from patients with RSTS}

We examined by qRT-PCR whether the mutations into the $C R E B B P$ locus affected the level of CBP transcripts. These assays revealed that the cell lines derived from seven of the nine

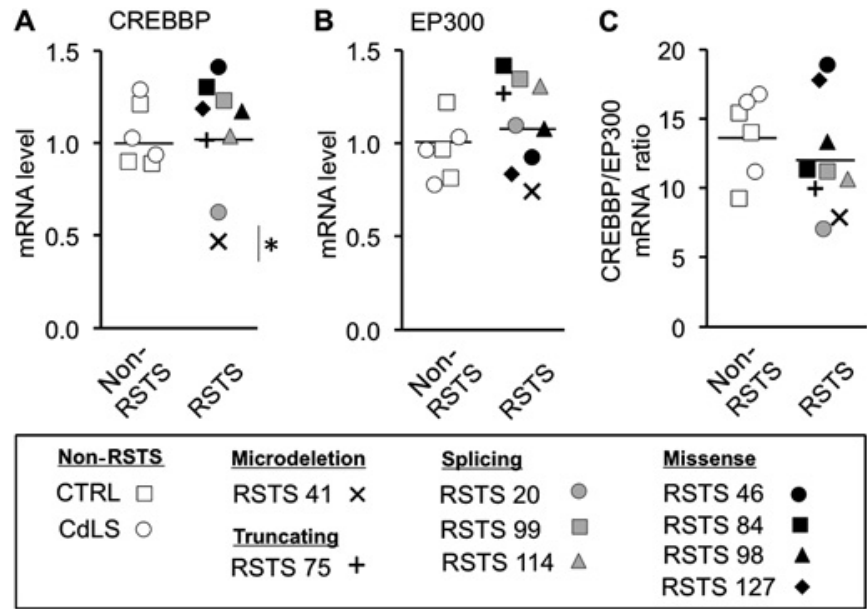

Figure 2 CBP and p300 transcript levels in Rubinstein-Taybi syndrome (RSTS) and control lymphoblastoid cell lines. A-B. mRNA levels for CREBBP (A) and EP300 (B), normalised to GAPDH mRNA levels, in the cell lines derived from patients with RSTS and control cell lines (non-RSTS). White squares ( $\square$ ) depict cell lines derived from healthy control individuals (CTRL), and white circles $(O)$ represent cell lines established from patients with CdLS. The symbol legend for RSTS cell lines is at the bottom of the figure (see also figure 1B). Symbols in the figure denote one cell line and represent the average of three to five individual measurements. Cell line from patient 41 carries a whole gene deletion of the CREBBP locus and shows a significant reduction of CBP transcripts compared to control cell lines and to CdLS-derived cell lines $l^{*} \mathrm{p}<0.05$, one-way analysis of variance followed by Tukey post hoc test). $n=3-5$ samples per group. $C$. The graph shows relative abundance of CBP and p300 transcripts. Since the efficiency of the two qRT-PCR primer pairs is the same, this result indicates that CBP is much more highly expressed than p300 in the lymphoblastoid cell lines.

patients with RSTS showed the same level of CBP transcripts as the control lines derived from healthy individuals and patients with CdLS (figure 2A). Patient 41, who carries a complete deletion of a CREBBP allele, had half-level of mRNA. Patient 20, whose mutation produces an aberrant transcript lacking part of exon $28,{ }^{12}$ also showed a similar reduction of CBP transcript since one of the primers used for qRT-PCR mapped in the sequence missing in this patient. The absence of significant changes in the other lines indicates that despite the genomic mutations, the mutant or truncated transcripts are stable and have a similar transcription rate as the wild-type transcripts. This was the case even for the cell line derived from patient 75, who carries an early truncating mutation and likely produces untranslatable transcripts potentially prone to accelerated decay. We also tested whether CBP deficiency led to the upregulation of EP300 expression given the high homology between these two genes. P300-specific qRT-PCR assays in the 15 cell lines did not reveal any significant difference at the level of transcription, indicating that there is no compensation of $\mathrm{CBP}$ reduction through overexpression of p300 mRNA (figure 2B). Interestingly, our qRT-PCR analysis indicates that the level of CBP transcripts in these cells is almost one order of magnitude larger than for p300 transcripts (figure 2C).

\section{Chromatin acetylation deficits in cell lines from patients with RSTS}

We next obtained protein extracts from cultures in exponential growth for each cell line and assessed for histone acetylation deficits through western blotting using an array of antibodies raised against different Lys in the $\mathrm{N}$-termini of histones $\mathrm{H} 2 \mathrm{~A}$, 
Figure 3 Altered levels of histone acetylation in cell lines from patients with Rubinstein-Taybi syndrome (RSTS). A. Representative images of western blot results showing protein levels of acetylated chromatin core histones $\mathrm{H} 2 \mathrm{~A}, \mathrm{H} 2 \mathrm{~B}, \mathrm{H} 3$, and $\mathrm{H} 4$, and total levels of histones $\mathrm{H} 2 \mathrm{~B}$ and $\mathrm{H} 3$ and $\beta$-actin in cell lysates from control individuals and patients with RSTS carrying mutations at the CREBBP locus. B-G. Semiquantitative densitometric analysis of western blots showing significant reduction in $\mathrm{AcH} 2 \mathrm{~A}$ and $\mathrm{AcH} 2 \mathrm{~B}$ levels in RSTS cell lines. Experimental conditions and symbols as in figure 2. Symbols in the figure denote one cell line and represent the fold change average value over control for three to eight independent cultures; see table 2 for statistical analysis of these experiments. Protein levels in $B-G$ are expressed as fold change over control upon normalisation for $\beta$-actin. $\left({ }^{*} \mathrm{p}<0.05\right.$, Mann-Whitney U test).
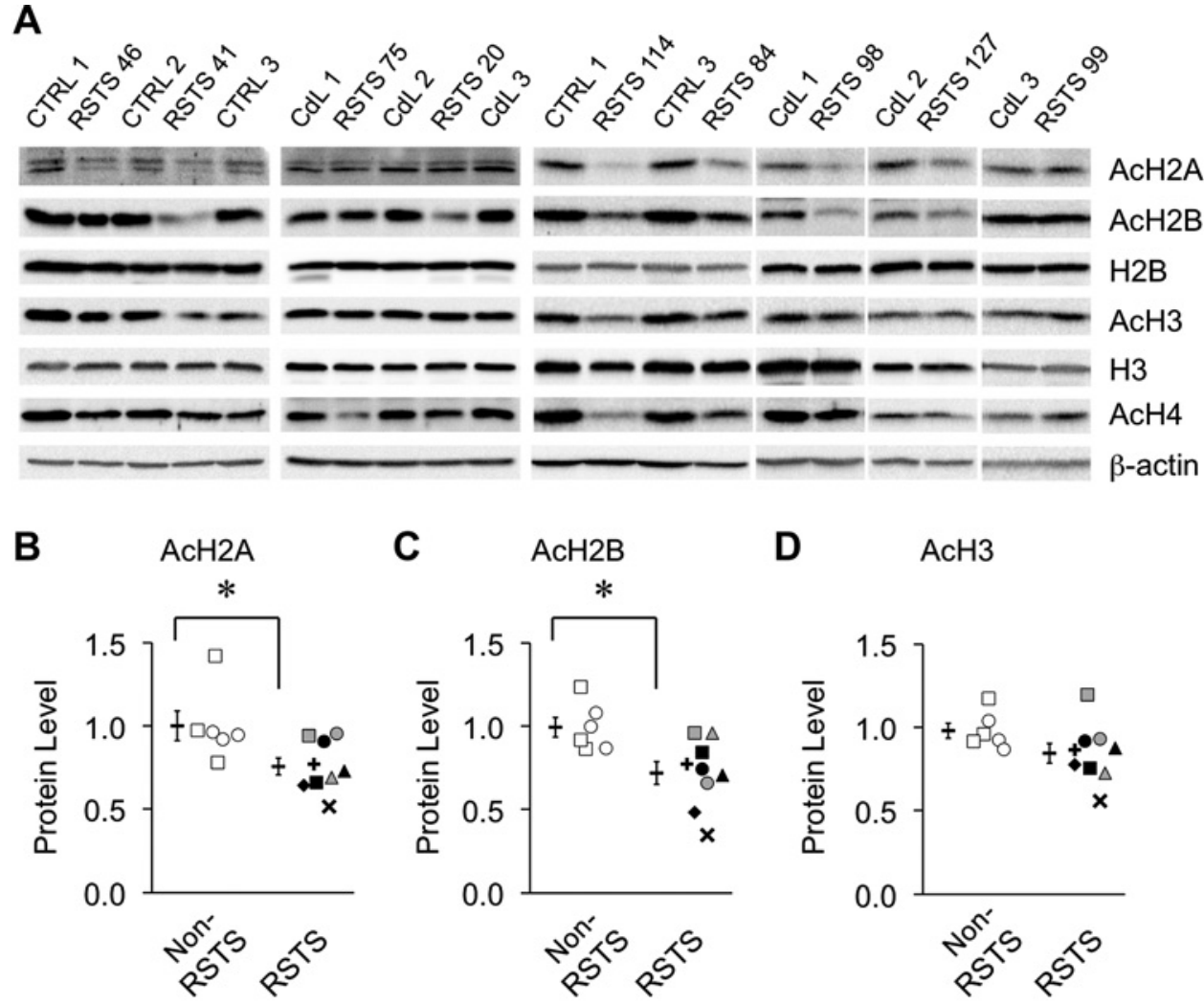

D

$\mathrm{AcH} 3$

E

$\mathbf{F}$

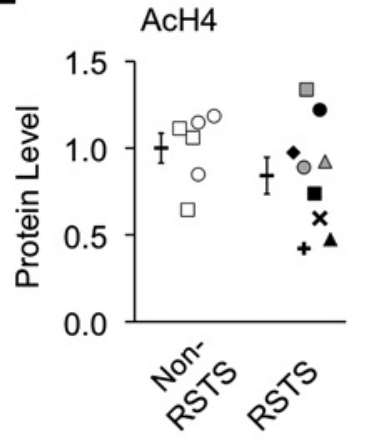

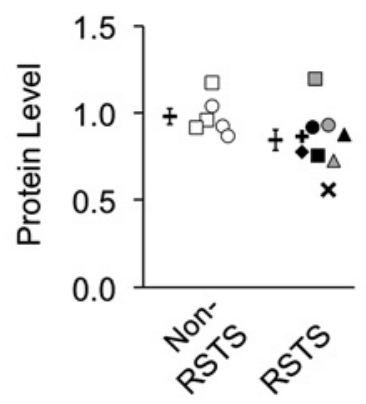

G

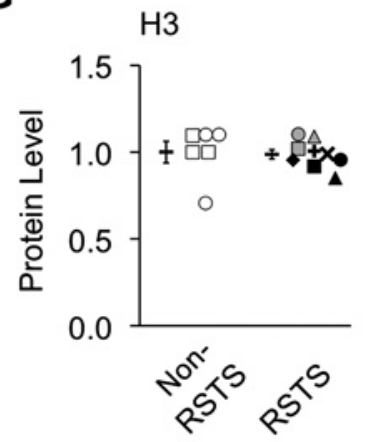

\begin{tabular}{|c|c|c|c|c|}
\hline Non-RSTS & Microdeletion & Splicing & & Missense \\
\hline CTRL $\square$ & RSTS $41 \times$ & RSTS 20 & ○ & RSTS 46 \\
\hline CdLS $\bigcirc$ & $\begin{array}{l}\text { Truncating } \\
\text { RSTS } 75+\end{array}$ & $\begin{array}{l}\text { RSTS } 99 \\
\text { RSTS } 114\end{array}$ & $\begin{array}{l}\square \\
\triangle\end{array}$ & $\begin{array}{l}\text { RSTS } 84 \\
\text { RSTS } 98 \\
\text { RSTS } 127\end{array}$ \\
\hline
\end{tabular}

$\mathrm{H} 2 \mathrm{~B}, \mathrm{H} 3$ and $\mathrm{H} 4$. The acetylation test revealed significant differences in the level of histone H2A and H2B between the cell lines derived from patients with RSTS (considered as a group) and either one of the two control groups (figure 3). In contrast, histones $\mathrm{H} 3$ and $\mathrm{H} 4$ showed levels of histone acetylation that did not differ from those observed in samples from healthy controls and patients with CdLS. Our experiments also revealed apparent differences between the different RSTS cell lines. Whereas line RSTS41 showed robust histone acetylation deficits affecting several histones, most lines showed more modest and specific deficits, and line RSTS99 was not distinguishable from the control lines (table 2). In particular, we observed the biggest deficits in the lines derived from patients $41,75,127,84$ and 98.
Treatment with HDACi reverses the histone acetylation deficits of RSTS-derived cells

The acetylation of histones is regulated by the counteracting activity of KAT and histone deacetylase enzymes that respectively add or remove acetyl groups from histones. We next tested whether the treatment with an inhibitor of histone acetyltransferases (HDACi) reversed the hypoacetylation of histones. Towards this end, we selected the cell line showing the largest deficit, RSTS41, and treated the cultures either with the HDACi TSA or with the vehicle DMSO. Like previously reported for CBP-deficient mice, ${ }^{36} 40$ western blotting analysis of protein extracts from cell cultures treated with TSA showed a level of bulk histone $\mathrm{H} 2 \mathrm{~B}$ acetylation higher than that observed in mutant and control cell lines treated with vehicle (figure 4A). To 
Table 2 Summary of the densitometric analysis of immunoblots against histone levels in cell lines from patients with RSTS

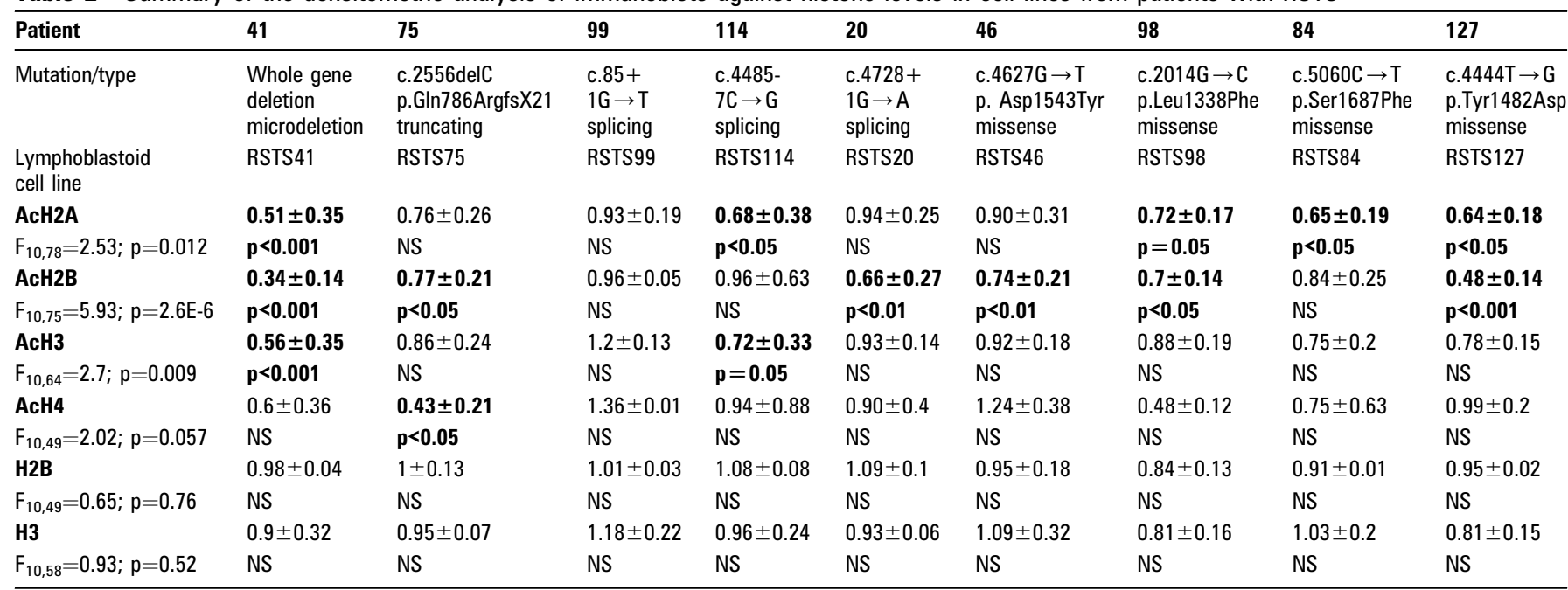

Data are expressed as means \pm SEM. Significant differences between groups (one-way analysis of variance followed by Fisher's protected least significant difference post hoc test) are shown in bold.

$\mathrm{n}=3-8$ samples per group.

NS, not significant.

confirm the rescue of the acetylation deficit using an alternative technique, we used flow cytometry. Cells were fixed, permeabilised, stained with anti-AcH2B antibody and analysed in a FACSAria III cell sorter. We did not observe differences in the forward scatter/side scatter distribution between genotypes or treatments, indicating that TSA did not affect cell viability. This experiment confirmed the reduction of histone $\mathrm{H} 2 \mathrm{~B}$ acetylation in cells derived from patient 41 when compared to a control cell line and the reversal of the deficit upon treatment with TSA (figure 4B-C).

\section{DISCUSSION}

We reported here the identification of six new mutations in the CREBBP gene associated to RSTS, widening the spectrum of mutations associated to this disorder. In addition, we investigated the possible histone acetylation deficits in lymphoblastoid cell lines derived from nine patients carrying different types of mutation in the CREBBP gene including those carrying the novel mutations and three previously reported patients. ${ }^{12} 20 \mathrm{We}$ observed deficits in histone acetylation in most of these cell lines that are similar to those observed in the brain of mice deficient in CBP activity, effectively translating seminal observations in mouse models of RSTS to humans.

The examination of the acetylation state of the four nucleosome histones in the nine cell lines generated from individuals with RSTS and the six lines from healthy individuals or mentally impaired individuals with a different pathology revealed consistent abnormalities. The acetylation assay of the four nucleosome histones shows a general reduction of bulk acetylation levels in patients with RSTS as compared to the controls, particularly for histone $\mathrm{H} 2 \mathrm{~B}$ and $\mathrm{H} 2 \mathrm{~A}$. The worst deficit was observed in the cell line from patient 41 bearing a CBP null allele and showing severe mental retardation. Variable acetylation deficits were observed in patients that are carriers of missense and splicing mutations. The cells from patients 98, 75, 127 and 114 showed significant deficits affecting the acetylation state of more than one histone, whereas those from patients 20 , 84 and 46 showed milder defects. Finally, the cells derived from patient 99 (which carry a splicing mutation that predicts a prematurely truncated protein) did not show any significant deficit, although we cannot exclude that, in the absence of apparent alterations at the bulk histone acetylation level, there were defects in specific genomic loci. Given the very limited impact of the splicing mutation in RSTS99 cells, we hypothesise that the splicing alteration in this patient may be partial. Although, in the most extreme examples, we observe certain correlation between cognitive impairments and epigenetic alterations in the cell lines, overall, it is difficult to correlate the severity of the molecular alterations and specific symptoms of the disease. In line with the limited effect of some of the mutations affecting the KAT domain in our analyses, two recent studies using primary murine embryonic fibroblasts from CBP/ p300 cre-deleted double knockout mice showed that mutant CBP proteins carrying missense mutations that disrupt the KAT domain, including mutations such as Q1500P, previously associated to RSTS, still retain significant KAT activity and their expression only results in a modest reduction in H3K18 acetylation when compared to wild-type CBP. ${ }^{44} 45$

Although the role of CBP and p300 as KAT proteins has been investigated in animal models of the disease, this represents the first study on acetylation capability performed in human cell lines obtained from patients with RSTS who are carrier of different CREBBP genetic lesions. The lack to access to diseased neural tissue of patients with RSTS severely limits the translation of molecular observation in animal models to the clinic. The use of peripheral blood and derived immortalised cell lines can however provide some initial insight into the molecular aetiology of the disease till the generation of RSTS-specific induced pluripotent stem cells and their differentiation to neurons. ${ }^{46}$ Thus, the detection of histone acetylation deficits in samples from patients with RSTS is of considerable value for understanding the molecular aetiology of this disorder. It has been suggested that histone acetylation/deacetylation in neurons play a critical role in memory, addiction, neurogenesis and other forms of neural plasticity. ${ }^{47}$ As a consequence, some cognitive and physiological deficits observed in RSTS may not simply be due to defects originating during development, but may result from the continued requirement of normal levels of KAT activity throughout life. ${ }^{34}$

Interestingly, the experiments with an HDACi in two RSTS cell lines showing significant deficits in the acetylation of histone $\mathrm{H} 2 \mathrm{~B}$ demonstrated a rescue of the defect, confirming the 
A

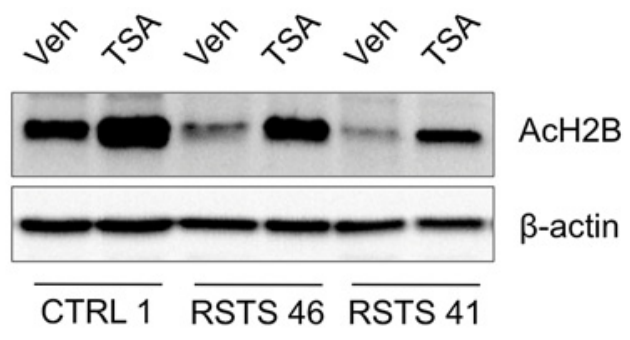

B
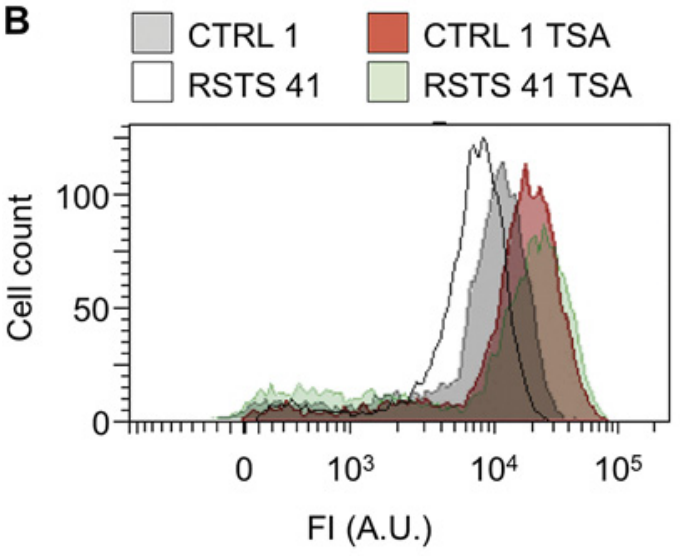

C

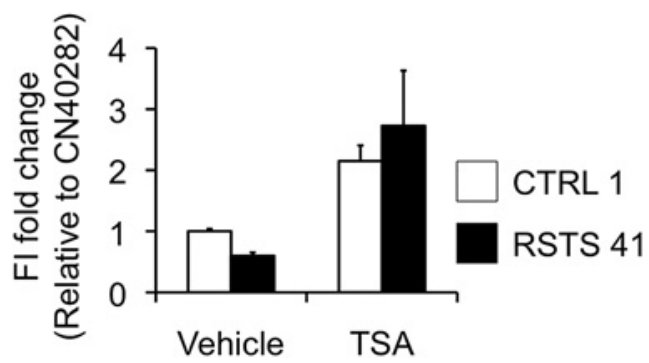

Figure 4 Trichostatin A (TSA) reverses the histone acetylation deficit. A. Immunoblot against acetylated histone $\mathrm{H} 2 \mathrm{~B}$ in a control cell line (CTRL) and in cell lines from patients 46 and 41 shows the reversion of hypoacetylation of $\mathrm{H} 2 \mathrm{~B}$ after TSA treatment $(2 \mu \mathrm{M}, 2 \mathrm{~h}$.). $\beta$-Actin was used as loading control. B. Frequency histograms of FACS data for AcH2B levels in a control line (CTRL) and in the cell line derived from patient 41 show reduced levels of histone H2B acetylation in the Rubinstein-Taybi syndrome (RSTS) cell line and increased levels of acetylation after TSA treatment $(2 \mu \mathrm{M}, 2 \mathrm{~h}$.) in control and RSTS cell lines. C. Bar graph showing FACS results expressed as fluorescence intensity (mean \pm SEM) normalised to CTRL treated with vehicle (dimethyl sulfoxide (DMSO)). $\mathrm{n}=2-4$ experiment per condition.

plasticity of the acetylation state and the possibility of modulating it, and paving the way to the idea of a therapeutic treatment of RSTS. Given the proven efficacy of $\mathrm{HDACi}$, including TSA, in RSTS mouse models, ${ }^{36} 3749$ the confirmation of the existence of similar biochemical deficits in cell lines from patients and their reversal by HDACi open new therapeutic possibilities. There is great interest in the pharmaceutical industry for developing 'epi-drugs' suitable for treating brain diseases. ${ }^{50}$ Various histone deacetylases, more specific and showing less noxious side effects than TSA, are currently being tested for the treatment of different forms of cancer and neurodegeneration. If the results of these clinical trials were positive and the new compounds show minimal side effects, it would be worthwhile to test their effectiveness also in the treatment of RSTS.
Acknowledgements We would like to thank the patients' families for participating in this study and the clinicians who provided some of the patients (Dr L. Garavelli, Clinical Genetics Unit, S. Maria Nuova Hospital Reggio Emilia; Dr M. Estienne, U.0. Neuropsichiatria infantile Fondazione IRCCS Istituto Neurologico Carlo Besta). We would also like to thank the Galliera Genetic Bank Italian Telethon project GTF4003 for providing the lymphoblastoid cell lines.

Funding This study was supported by the Italy-Spain bilateral MIUR project (referred to as IT08143C4F in Italy and HI2007-0203 in Spain). Research at Larizza's lab is supported by a grant from ASM (Associazione Studio Malformazioni). Research at Barco's lab is supported by the grants from the Spanish Ministry of Science and Innovation BFU2008-00611, CSD2007-00023 and SAF2008-03194-E (part of the coordinated ERA-Net NEURON project Epitherapy) and a grant from Fundación Ramón Areces. JLA has a Juan de la Cierva contract given by the Spanish Ministry of Science and Innovation.

Competing interests None to declare.

Patient consent Obtained.

Ethics approval Ethics approval was provided by the University of Milan.

Contributors JPLA, CG, AB and LL conceived and designed the study and wrote the manuscript. JPLA performed the work in lymphoblastoid cell lines. CG, FM and SP performed the patients screen. MP, GS and AS recruited the patients and collected the clinical information.

Provenance and peer review Not commissioned; externally peer reviewed.

\section{REFERENCES}

1. Rubinstein JH, Taybi H. Broad thumbs and toes and facial abnormalities. A possible mental retardation syndrome. Am J Dis Child 1963;105:588-608.

2. Miller RW, Rubinstein JH. Tumors in Rubinstein-Taybi syndrome. Am J Med Genet 1995;56:112-15

3. Masuno M, Imaizumi K, Ishii T, Kuroki Y, Baba N, Tanaka Y. Pilomatrixomas in Rubinstein-Taybi syndrome. Am J Med Genet 1998;77:81-2.

4. Hennekam RC, Baselier AC, Beyaert E, Bos A, Blok JB, Jansma HB, ThorbeckeNilsen VV, Veerman H. Psychological and speech studies in Rubinstein-Taybi syndrome. Am J Ment Retard 1992;96:645-60.

5. Hennekam RC. Rubinstein-Taybi syndrome. Eur J Hum Genet 2006;14:981-5

6. Petrij F, Giles RH, Dauwerse HG, Saris JJ, Hennekam RC, Masuno M, Tommerup N van Ommen GJ, Goodman RH, Peters DJ. Rubinstein-Taybi syndrome caused by mutations in the transcriptional co-activator CBP. Nature 1995;376:348-51.

7. Roelfsema JH, White SJ, Ariyürek Y, Bartholdi D, Niedrist D, Papadia F, Bacino CA den Dunnen JT, van Ommen GJ, Breuning MH, Hennekam RC, Peters DJ. Genetic heterogeneity in Rubinstein-Taybi syndrome: mutations in both the CBP and EP300 genes cause disease. Am J Hum Genet 2005;76:572-80.

8. Balci S, Ali Ergun M, Lechno S, Bartsch O. Rubinstein-Taybi syndrome in first cousins with different de novo mutations. Am J Med Genet A 2010;152A:1036-8.

9. Bartsch 0, Kress W, Kempf O, Lechno S, Haaf T, Zechner U. Inheritance and variable expression in Rubinstein-Taybi syndrome. Am J Med Genet A 2010;152A:2254-61.

10. Bartsch O, Locher K, Meinecke P, Kress W, Seemanová E, Wagner A, Ostermann K Rödel G. Molecular studies in 10 cases of Rubinstein-Taybi syndrome, including a mild variant showing a missense mutation in codon 1175 of CREBBP. J Med Genet 2002;39:496-501.

11. Bartsch 0, Schmidt S, Richter M, Morlot S, Seemanová E, Wiebe G, Rasi S. DNA sequencing of CREBBP demonstrates mutations in $56 \%$ of patients with Rubinstein-Taybi syndrome (RSTS) and in another patient with incomplete RSTS. Hum Genet 2005;117:485-93.

12. Bentivegna A, Milani D, Gervasini $C$, Castronovo $P$, Mottadelli $F$, Manzini $S$, Colapietro P, Giordano L, Atzeri F, Divizia MT, Uzielli ML, Neri G, Bedeschi MF, Faravelli F, Selicorni A, Larizza L. Rubinstein-Taybi syndrome: spectrum of CREBBP mutations in Italian patients. BMC Med Genet 2006;7:77.

13. Coupry I, Monnet L, Attia AA, Taine L, Lacombe D. Arveiler B. Analysis of CBP (CREBBP) gene deletions in Rubinstein-Taybi syndrome patients using real-time quantitative PCR. Hum Mutat 2004;23:278-84

14. Coupry I, Roudaut C, Stef M, Delrue MA, Marche M, Burgelin I, Taine L, Cruaud C Lacombe D, Arveiler B. Molecular analysis of the CBP gene in 60 patients with Rubinstein-Taybi syndrome. J Med Genet 2002;39:415-21.

15. Kalkhoven $\mathbf{E}$, Roelfsema $\mathrm{JH}$, Teunissen $\mathrm{H}$, den Boer $\mathrm{A}$, Ariyurek $\mathrm{Y}$, Zantema $\mathrm{A}$ Breuning MH, Hennekam RC, Peters DJ. Loss of CBP acetyltransferase activity by $\mathrm{PHD}$ finger mutations in Rubinstein-Taybi syndrome. Hum Mol Genet 2003:12:441-50

16. Li C, Szybowska M. A novel mutation c.4003 G>C in the CREBBP gene in an adult female with Rubinstein-Taybi syndrome presenting with subtle dysmorphic features. Am J Med Genet A 2010;152A:2939-41.

17. Murata T, Kurokawa R, Krones A, Tatsumi K, Ishii M, Taki T, Masuno M, Ohashi H Yanagisawa M, Rosenfeld MG, Glass CK, Hayashi Y. Defect of histone acetyltransferase activity of the nuclear transcriptional coactivator CBP in Rubinstein-Taybi syndrome. Hum Mol Genet 2001;10:1071-6.

18. Udaka T, Samejima H, Kosaki R, Kurosawa K, Okamoto N, Mizuno S, Makita $Y$, Numabe H, Toral JF, Takahashi T, Kosaki K. Comprehensive screening of CREB- 
binding protein gene mutations among patients with Rubinstein-Taybi syndrome using denaturing high-performance liquid chromatography. Congenit Anom (Kyoto) 2005; 45:125-31.

19. Petrij F, Dauwerse HG, Blough RI, Giles RH, van der Smagt JJ, Wallerstein R, Maaswinkel-Mooy PD, van Karnebeek CD, van Ommen GJ, van Haeringen A, Rubinstein JH, Saal HM, Hennekam RC, Peters DJ, Breuning MH. Diagnostic analysis of the Rubinstein-Taybi syndrome: five cosmids should be used for microdeletion detection and low number of protein truncating mutations. $J$ Med Genet 2000;37:168-76.

20. Gervasini C, Castronovo P, Bentivegna A, Mottadelli F, Faravelli F, GiovannucciUzielli ML, Pessagno A, Lucci-Cordisco E, Pinto AM, Salviati L, Selicorni A, Tenconi R, Neri G, Larizza L. High frequency of mosaic CREBBP deletions in Rubinstein-Taybi syndrome patients and mapping of somatic and germ-line breakpoints. Genomics 2007;90:567-73.

21. Breuning MH, Dauwerse HG, Fugazza G, Saris JJ, Spruit L, Wijnen H, Tommerup N, van der Hagen CB, Imaizumi K, Kuroki Y, van den Boogaard MJ, de Pater JM, Mariman EC, Hamel BC, Himmelbauer H, Frischauf AM, Stallings R, Beverstock GC, van Ommen GJ, Hennekam RC. Rubinstein-Taybi syndrome caused by submicroscopic deletions within 16p13.3. Am J Hum Genet 1993;52:249-54.

22. Imaizumi K, Kurosawa K, Masuno M, Tsukahara M, Kuroki Y. Chromosome aberrations in Rubinstein-Taybi syndrome. Clin Genet 1993;43:215-16.

23. Lacombe D, Saura R, Taine L, Battin J. Confirmation of assignment of a locus for Rubinstein-Taybi syndrome gene to 16p13.3. Am J Med Genet 1992;44:126-8.

24. Tommerup N, van der Hagen CB, Heiberg A. Tentative assignment of a locus for Rubinstein-Taybi syndrome to $16 p 13.3$ by a de novo reciprocal translocation, $t(7 ; 16)$ (q34;p13.3). Am J Med Genet 1992;44:237-41.

25. Wallerstein R, Anderson CE, Hay B, Gupta P, Gibas L, Ansari K, Cowchock FS, Weinblatt V, Reid C, Levitas A, Jackson L. Submicroscopic deletions at 16p13.3 in Rubinstein-Taybi syndrome: frequency and clinical manifestations in a North American population. J Med Genet 1997;34:203-6.

26. Bartholdi D, Roelfsema JH, Papadia F, Breuning MH, Niedrist D, Hennekam RC, Schinzel A, Peters DJ. Genetic heterogeneity in Rubinstein-Taybi syndrome: delineation of the phenotype of the first patients carrying mutations in EP300. J Med Genet 2007:44:327-33

27. Zimmermann N, Acosta AM, Kohlhase J, Bartsch 0. Confirmation of EP300 gene mutations as a rare cause of Rubinstein-Taybi syndrome. Eur J Hum Genet 2007;15:837-42.

28. Foley P, Bunyan D, Stratton J, Dillon M, Lynch SA. Further case of Rubinstein-Taybi syndrome due to a deletion in EP300. Am J Med Genet A 2009:149A:997-1000.

29. Tsai AC, Dossett CJ, Walton CS, Cramer AE, Eng PA, Nowakowska BA, Pursley AN, Stankiewicz P, Wiszniewska J, Cheung SW. Exon deletions of the EP300 and CREBBP genes in two children with Rubinstein-Taybi syndrome detected by aCGH. Eur $J$ Hum Genet 2011;19:43-9.

30. Ogryzko VV, Schiltz RL, Russanova V, Howard BH, Nakatani Y. The transcriptional coactivators p300 and CBP are histone acetyltransferases. Cell 1996;87:953-9.

31. Allis CD, Berger SL, Cote J, Dent S, Jenuwien T, Kouzarides T, Pillus L, Reinberg D, Shi Y, Shiekhattar R, Shilatifard A, Workman J, Zhang Y. New nomenclature for chromatin-modifying enzymes. Cell 2007;131:633-6.

32. Giordano A, Avantaggiati ML. p300 and CBP: partners for life and death. J Cell Physiol 1999;181:218-30.

33. Kalkhoven E. CBP and p300: HATs for different occasions. Biochem Pharmacol 2004;68:1145-55.

34. Barco A. The Rubinstein-Taybi syndrome: modeling mental impairment in the mouse. Genes Brain Behav 2007;6(Suppl 1):32-9.
35. Lopez-Atalaya JP, Ciccarelli A, Viosca J, Valor LM, Jimenez-Minchan M, Canals S Giustetto M, Barco A. CBP is required for environmental enrichment-induced neurogenesis and cognitive enhancement. EMBO J. Published Online First: 16 August 2011. doi:10.1038/emboj.2011.299.

36. Alarcon JM, Malleret G, Touzani K, Vronskaya S, Ishii S, Kandel ER, Barco A. Chromatin acetylation, memory, and LTP are impaired in CBP +/- mice: a model for the cognitive deficit in Rubinstein-Taybi syndrome and its amelioration. Neuron 2004:42:947-59

37. Korzus $\mathbf{E}$, Rosenfeld MG, Mayford M. CBP histone acetyltransferase activity is a critical component of memory consolidation. Neuron 2004;42:961-72.

38. Wood MA, Kaplan MP, Park A, Blanchard EJ, Oliveira AM, Lombardi TL, Abel T. Transgenic mice expressing a truncated form of CREB-binding protein (CBP) exhibit deficits in hippocampal synaptic plasticity and memory storage. Learn Mem 2005:12:111-19

39. Chen G, Zou X, Watanabe H, van Deursen JM, Shen J. CREB binding protein is required for both short-term and long-term memory formation. J Neurosci 2010:30:13066-77.

40. Valor LM, Pulopulos MM, Jimenez-Minchan M, Olivares R, Lutz B, Barco A. Ablation of $\mathrm{CBP}$ in forebrain principal neurons causes modest memory and transcriptional defects and a dramatic reduction of histone acetylation, but does not affect cell viability. J Neurosci 2011;31:1652-63.

41. Barrett RM, Malvaez M, Kramar E, Matheos DP, Arrizon A, Cabrera SM, Lynch G, Greene RW, Wood MA. Hippocampal focal knockout of CBP affects specific histone modifications, long-term potentiation, and long-term memory. Neuropsychopharmacology 2011;36:1545-56.

42. Viosca J, Lopez-Atalaya JP, Olivares R, Eckner R, Barco A. Syndromic features and mild cognitive impairment in mice with genetic reduction on p300 activity: differential contribution of p300 and CBP to Rubinstein-Taybi syndrome etiology. Neurobiol Dis 2010;37:186-94

43. Sanchis-Segura C, Lopez-Atalaya JP, Barco A. Selective boosting of transcriptiona and behavioral responses to drugs of abuse by histone deacetylase inhibition. Neuropsychopharmacology 2009;34:2642-54.

44. Mullighan CG, Zhang J, Kasper LH, Lerach S, Payne-Turner D, Phillips LA, Heatley SL, Holmfeldt L, Collins-Underwood JR, Ma J, Buetow KH, Pui CH, Baker SD, Brindle PK, Downing JR. CREBBP mutations in relapsed acute lymphoblastic leukaemia. Nature 2011:471:235-9.

45. Pasqualucci L, Dominguez-Sola D, Chiarenza A, Fabbri G, Grunn A, Trifonov V, Kasper LH, Lerach S, Tang H, Ma J, Rossi D, Chadburn A, Murty VV, Mullighan CG, Gaidano G, Rabadan R, Brindle PK, Dalla-Favera R. Inactivating mutations of acetyltransferase genes in B-cell lymphoma. Nature 2011;471:189-95.

46. Brennand KJ, Simone A, Jou J, Gelboin-Burkhart C, Tran N, Sangar S, Li Y, Mu Y, Chen G, Yu D, McCarthy S, Sebat J, Gage FH. Modelling schizophrenia using human induced pluripotent stem cells. Nature 2011;473:221-5.

47. Borrelli E, Nestler EJ, Allis CD, Sassone-Corsi P. Decoding the epigenetic language of neuronal plasticity. Neuron 2008;60:961-74.

48. Zocchi L, Sassone-Corsi P. Joining the dots: from chromatin remodeling to neurona plasticity. Curr Opin Neurobiol 2010;20:432-40.

49. Vecsey CG, Hawk JD, Lattal KM, Stein JM, Fabian SA, Attner MA, Cabrera SM, McDonough CB, Brindle PK, Abel T, Wood MA. Histone deacetylase inhibitors enhance memory and synaptic plasticity via CREB: CBP-dependent transcriptional activation. J Neurosci 2007;27:6128-40.

50. Kazantsev AG, Thompson LM. Therapeutic application of histone deacetylase inhibitors for central nervous system disorders. Nat Rev Drug Discov 2008; 7:854-68. 


\title{
Histone acetylation deficits in lymphoblastoid cell lines from patients with Rubinstein-Taybi syndrome
}

\author{
J P Lopez-Atalaya, C Gervasini, F Mottadelli, et al. \\ $J$ Med Genet published online October 7, 2011 \\ doi: 10.1136/jmedgenet-2011-100354
}

Updated information and services can be found at:

http://jmg.bmj.com/content/early/2011/10/07/jmedgenet-2011-100354.full.html

These include:

References This article cites 49 articles, 12 of which can be accessed free at: http:/jjmg.bmj.com/content/early/2011/10/07/jmedgenet-2011-100354.full.html\#ref-list-1

$\mathbf{P}<\mathbf{P} \quad$ Published online October 7, 2011 in advance of the print journal.

Email alerting Receive free email alerts when new articles cite this article. Sign up in service the box at the top right corner of the online article.

Topic Articles on similar topics can be found in the following collections

Collections

Calcium and bone (262 articles)

Genetic screening / counselling (688 articles)

Notes

Advance online articles have been peer reviewed, accepted for publication, edited and typeset, but have not not yet appeared in the paper journal. Advance online articles are citable and establish publication priority; they are indexed by PubMed from initial publication. Citations to Advance online articles must include the digital object identifier (DOIs) and date of initial publication.

To request permissions go to:

http://group.bmj.com/group/rights-licensing/permissions

To order reprints go to:

http://journals.bmj.com/cgi/reprintform

To subscribe to BMJ go to:

http://group.bmj.com/subscribe/ 